\title{
Penggunaan Teknologi Multimedia Pada Pembelajaran Literasi Anak Usia Dini
}

\author{
Khikmah Novitasari \\ Universitas PGRI Yogyakarta, \\ .Email:khiknov@gmail.com
}

\begin{abstract}
Abstrak
Penelitian ini bertujuan untuk mendeskripsikan penggunaan teknologi multimedia pada pembelajaran literasi anak usia dini, meliputi pelaksanaan penggunaan teknologi multimedia pada pembelajaran literasi anak usiaa 5-6 tahun. Penelitian ini merupakan penelitian kualitatif. Pengumpulan data menggunakan teknik observasi, wawancara dan kajian dokumen. Keabsahan data diperoleh melalui triangulasi data. Teknik analisis data dilakukan dengan model interaktif. Hasil penelitian menunjukkan bahwa: Pelaksanaan penggunaan teknologi multimedia pada pembelajaran literasi diimplementasikan dalam pijakan-pijakan pembelajaran sentra dengan langkah-langkah: (a) pemusatan perhatian dan fokus, (b) orientasi, (c) pemodelan, (d) tahap bermain anak, dan (e) ringkasan.
\end{abstract}

Kata Kunci: anak usia dini; pembelajaran literasi; teknologi multimedia, ,

\begin{abstract}
This study was aimed to describe the use of multimedia technology for literacy learning in early childhood education, including: implementation of multimedia technology utilization in children's literacy learning. This study was a qualitative research. Data collection used observation techniques, interviews and document review. The data validity was obtained through triangulation. The data analysis technique was done using interactive model. The results show that: Implementation of use of multimedia technology in literacy learning was implemented in each step of learning centers with steps:(a) focusing attention, (b) orientation, (c) modeling, (d) child play stage, and (e) summary.
\end{abstract}

Keywords: early childhood; literacy learning; multimedia technology,

\section{PENDAHULUAN}

Literasi merupakan salah satu bidang keterampilan akademik yang paling penting karena mempengaruhi perolehan keterampilan di bidang akademik lainnya. Kemampuan literasi yang baik dapat memperluas cakrawala pengetahuan, memberikan inspirasi atau solusi bahkan membuka banyak peluang baru. Hasil penelitian oleh Senechal \& LeFreve menunjukkan bahwa kemampuan literasi awal yang baik membantu anak lebih mudah belajar membaca dan meningkatkan kesuksesan anak di sekolah (Ruhaena, 2014, p.1). Selain itu, Allington menyatakan bahwa kemampuan literasi awal anak dapat memprediksi kemampuan literasi selanjutnya pada tingkat sedang sampai tinggi (Trehearne, 2011, p.34). Anak yang sudah menguasai kemampuan literasi sejak dini akan menyebabkan anak menjadi seorang pebelajar sepanjang hidupnya. 
Kemampuan literasi atau membaca dan menulis anak di Indonesia masih tergolong rendah. Hal ini dapat dilihat dari hasil penelitian PIRLS (Progress in International Reading Literacy Study) tahun 2011, yang menunjukkan bahwa rata-rata kemampuan memahami bacaan siswa kelas IV SD dan MI di Indonesia memperoleh skor 428, yang masih di bawah skor rata-rata 500, dan menduduki peringkat ke 42 dari 45 negara yang diteliti (Mullis, et all., 2012, p.38). Kemampuan literasi awal anak, mempengaruhi kemampuan literasi anak di masa yang akan datang. Artinya, kemampuan literasi siswa SD/MI yang rendah di atas, dipengaruhi juga oleh stimulasi yang diterima anak saat sebelum masuk jenjang sekolah dasar (Kennedy, 2012, p.190). Maka dari itu, sangatlah penting untuk membiasakan anak melakukan aktivitas literasi sejak usia dini, baik dilakukan di rumah sebagai aktivitas literasi dengan orangtua, maupun disekolah sebagai pembelajaran literasi yang dilakukan bersama guru.

Penggunaan teknologi multimedia saat ini telah membuka satu era baru dalam perkembangan media yang digunakan pada proses belajar dan mengajar di Taman Kanak-kanak. Teknologi multimedia ini mampu menggabungkan berbagai media seperti: teks, suara, gambar, numeric, animasi dan video dalam satu software digital, serta mempu nyai kemampuan interaktif. Multimedia dianggap sebagai media belajar dan mengajar yang menarik berdasarkan kemampuannya menyentuh berbagai indera: penglihatan, pendengaran dan sentuhan (Ramli, 2013, p.57). Hal ini menjadi satu alternatif yang baik sebagai alat bantu proses belajar dan mengajar.

Multimedia merupakan salah satu faktor dari banyaknya faktor yang memiliki pengaruh paling besar dalam pertumbuhan, perkembangan secara psikologis dan perubahan perilaku di segala usia, khususnya anak-anak. Menyikapi pengaruh teknologi multimedia terhadap perkembangan anak yang demikian, para pendidik harus mengetahui terlebih dahulu tentang substansi teknologi multimedia dan mampu menjadi bagian dari mereka. Artinya, tidak gagap teknologi, dan dari pengetahuan tersebut para pendidik mampu memaksimalkan sisi positifnya dan tahap demi tahap bisa meminimalisasi dampak negatifnya.

Aktivitas literasi yang memanfaatkan teknologi multimedia akan lebih mendukung proses belajar literasi, karena mengintegrasikan tulisan dengan gambar, animasi dan suara. Hal ini sangat menarik bagi anak karena mendapatkan stimulus melalui banyak indera sensorisnya, tidak hanya melihat dan mendengar saja. Multimedia yang bersifat multisensoris mampu memfungsi lebih banyak reseptor sehingga input yang masuk ke otak menjadi lebih kuat dan memudahkan proses info yang masuk ke dalam otak. Selain itu, dengan teknologi multimedia, anak terbantu untuk memahami lebih cepat hal-hal yang bersifat abstrak karena dapat disajikan dengan lebih konkret.

Media pembelajaran yang bermutu tinggi dapat meningkatkan kualitas pendidikan (Munir, 2012, p.143). Kehadiran media yang menarik dapat meningkatkan mutu pembelajaran (Munir, 2012, p.144). Teknologi multimedia adalah salah satu media yang menarik, sehingga teknologi multimedia merupakan salah satu media komunikasi pendidikan yang efektif digunakan untuk 
menyampaikan pesan dan memberikan penjelasan kepada peserta didik. Pesan instruksional multimedia adalah komunikasi menggunakan kata-kata dan gambar-gambar yang dimaksudkan untuk meningkatkan pembelajaran. Suatu pesan instruksional multimedia dalam komputer bisa meliputi narasi dan animasi. Menambahkan ilustrasi pada teks atau menambahkan animasi pada narasi maka itu bisa membantu anak lebih memahami materi/penjelasan yang disajikan (Mayer, 2009, p.116).

Kegiatan pembelajaran dengan menggunakan beberapa metode membaca permulaan yang tersimpan dalam perangkat lunak/software dan ditampilkan melalui multimedia berupa gambar, suara atau animasi serta strategy pembelajaran melalui pemanfaatan multimedia yang berfokus pada guru (presentasi, demontrasi, latihan dan praktek, diskusi, permainan) yang dirancang secara variatif dan menarik mampu menciptakan suasana belajar yang aktif dan menyenangkan (Jo, 2013, p.45). Artinya, pemanfaatan multimedia membawa keuntungan baik bagi guru maupun anak. Multimedia dapat memudahkan guru dalam menyampaikan materi pembelajaran literasi dan merancang lingkungan belajar yang menantang, sehingga terjadi perubahan sikap anak yang diikuti dengan peningkatan prestasi pada anak. Sayangnya, pendapat yang telah diuraikan di atas masih menjadi kotroversi. Beberapa masyarakat dan orangtua menganggap bahwa teknologi multimedia tidak memberikan pengaruh baik pada anak. Justru sebaliknya alatalat tersebut dapat menghambat perkembangan mereka. Beberapa ahli menemukan bahwa kehadiran media elektronik bersamaan dengan fragmentasi dari hypertext justru mengancam keberlanjutan kegiatan membaca (http://m.Kompasiana.com. 2012). Pendapat tersebut kemudian menjadi kekhawatiran bagi guru dalam menggunakan teknologi multimedia pada pembelajaran.

Hasil wawancara awal yang dilakukan peneliti kepada 10 guru Taman Kanak-kanak di Kabupaten Sleman menunjukkan bahwa masih terdapat kebingungan yang dialami oleh guru dalam menggunakan teknologi multimedia secara positif dalam proses pembelajaran di Taman Kanak-kanak. Tidak ada panduan dan contoh yang jelas bagaimana seharusnya penggunaan teknologi multimedia itu dilakukan dalam pembelajaran, khususnya dalam pembelajaran literasi anak. Padahal penggunaan teknologi multimedia saat ini menjadi faktor penting dalam pelaksanaan pembelajaran di era revolusi industri 4.0.

TK Model Sleman merupakan Taman Kanak-kanak yang menggunakan teknologi multimedia dalam pengembangan kemampuan literasi anak. Kurikulum yang digunakan dalam pembelajaran di TK Model Sleman adalah Kurikulum 2013 yang dipadukan dengan pembelajaran berbasis teknologi informasi. Hampir $50 \%$ pembelajaran di TK tersebut menggunakan teknologi multimedia. Penggunaan teknologi multimedia dalam pembelajaran literasi di TK ini, dapat menjadi model bagi TK-TK lain di Kabupaten Sleman. Oleh karena itu, penelitian penggunaan teknologi multimedia pembelajaran literasi di TK Model Sleman layak dilakukan.

\section{METODOLOGI}


Jenis penelitian ini adalah kualitatif. Penggunaan teknologi multimedia dalam pembelajaran yang akan diteliti ini meliputi perencanaan penggunaan teknologi multimedia dalam pembelajaran, pelaksanaan penggunaan teknologi multimedia dalam pembelajaran literasi dan penilaian kemampuan literasi anak kelompok B yang distimulasi menggunakan teknologi multimedia dalam kurikulum 2013 di TK Model Sleman.

Penelitian dilakukan di TK Model Sleman. TK Model Sleman beralamatkan di Blotan, Werdomartani, Sleman, Kabupaten Sleman, DIY. Penelitian ini dilaksanakan pada bulan Januari sampai bulan April tahun pelajaran 2016/2017. Pemilihan tempat atau lembaga penelitian didasarkan atas hasil observasi (pra penelitian) pada tanggal 3 September 2016.

Subjek penelitian ini adalah guru, kepala sekolah, dan seksi kurikulum di TK Model Sleman. Instrumen yang digunakan dalam penelitian ini adalah peneliti sendiri dengan menggunakan pedoman wawancara, pedoman observasi dan pedoman dokumentasi yang terstruktur. Penelitian membutuhkan beberapa metode pengumpulan data untuk mendapatkan data-data yang diinginkan. Pelaksanaan pengumpulan data dalam penelitian ini terdapat enam sumber yaitu: dokumen, rekaman arsip, wawancara, pengamatan langsung, observasi partisipan, dan perangkat-perangkat fisik (Yin, 2011, p.23). Penelitian ini menggunakan metode pengumpulan data melalui wawancara, observasi dan studi dokumentasi.

Keabsahan data pada penelitian ini dilakukan dengan menggunakan triangulasi, menggunakan bahan referensi, serta analisis kasus negatif. Analisis data yang digunakan adalah analisis komponen. Analisis data dilakukan dengan proses mencari dan menyusun secara sistematis data yang diperoleh dari hasil pengumpulan data seperti teknik observasi, wawancara, dan dokumentasi. Analisis data yang digunakan dalam penelitian ini adalah analisis interaktif model dari Miles \& Hiberman.

\section{HASIL DAN PEMBAHASAN}

Penggunaan teknologi multimedia dalam pembelajaran di TK Model Sleman terintegrasi dengan kegiatan pembelajaran pada kurikulum 2013 dengan model pembelajaran sentra dan pendekatan pembelajaran saintifik. Kegiatan pembelajaran dalam kurikulum 2013 dengan model pembelajaran sentra yang dimaksud adalah pijakan lingkungan main, pijakan pengalaman sebelum main, pijakan saat main dan pijakan setelah main. Pada pelaksanaan pembelajaran dengan menggunakan teknologi multimedia pada pembelajaran di TK Model Sleman, kegiatan pijakan lingkungan main diisi dengan tahap pemusatan perhatian dan fokus. Kegiatan pada pijakan pengalaman sebelum main, diisi dengan tahap orientasi dan tahap pemodelan. Pijakan saat main diisi dengan tahap bermain anak, dan kegiatan pada pijakan setelah main, diisi dengan tahap ringkasan. Langkah-langkah tersebut sesuai dengan langkah-langkah penggunaan teknologi multimedia yang dijelaskan oleh Adams \& Engelman (Chee \& Wong, 2003, pp.109116), yaitu: centralization of attention and focus, orientation, children's play, review and feedback. 
Pembelajaran literasi yang dilaksanakan di TK Model Sleman tidak terlepas dari penggunaan metode, pendekatan, dan model pembelajaran. Metode pembelajaran yang digunakan di TK Model Sleman ditentukan oleh guru, yaitu sesuai dengan rencana kegiatan pembelajaran hari itu, dan kreativitas guru. Trianto (2011, p.93) mengungkapkan metode merupakan cara yang digunakan untuk mengimplementasikan rencana yang sudah disusun dalam kegiatan nyata agar tujuan yang telah disusun tercapai secara optimal. Oleh karena itu, banyak metode yang dapat digunakan dalam penggunaan teknologi multimedia pada pembelajaran literasi, yaitu metode tanya jawab, metode bercerita, metode pemberian tugas, metode praktik langsung, dan metode unjuk kerja.

Metode-metode yang dilaksanakan di atas disesuaikan juga dengan pendekatan pembelajaran di TK Model Sleman. Pendekatan pembelajaran di TK ini adalah pendekatan saintifik. Penggunaan teknologi multimedia dalam pembelajaran literasi dilakukan dengan diintegrasikan pada pembelajaran berbasis saintifik. Pada saat anak belajar dengan menggunakan teknologi multimedia, anak-anak melakukan kgiatan mengamati gambar, menalar gambar atau materi yang ada pada layar komputer, menggali informasi menggunakan internet, bertanya kepada guru, dan mengkomunikasikan apa yang telah mereka dapatkan pada saat pembelajaran. Trianto (2011, pp.90-93) mengungkapkan bahwa pendekatan sebagai cara untuk mencapai tujuan. Oleh karena itu, penggunaan pendekatan sangat penting dalam pembelajaran literasi dengan menggunakan teknologi multimedia.

Aspek-aspek kemampuan literasi yang distimulasi dengan menggunakan teknologi multimedia di TK Model Sleman mengacu pada indikator pencapaian perkembangan anak usia dini usia 5-6 tahun pada kompetensi dasar 4.12, yaitu menunjukkan kemampuan literasi awal dengan berbagai karya, indikatornya adalah: menyebutkan simbol-simbol huruf yang dikenal, mengenal suara huruf awal dari nama benda-benda yang ada di sekitarnya, memahami hubungan antara bunyi dan bentuk huruf, membaca nama sendiri, menuliskan nama sendiri, memahami arti kata dalam cerita. Hal tersebut sejalan dengan pendapat Snow (2008, p.276) yang menyatakan bahwa pada usia 5 tahun anak dapat membaca suku kata, dapat mengenali kata-kata iregular dengan melihatnya, memprediksi apa yang akan terjadi dalam cerita, dan memantau pemahamannya ketika membaca serta dapat membuat tulisan untuk dibaca orang lain, sedangkan pada usia 6 tahun anak mampu mengenal huruf besar dan kecil, mengerti bahwa urutan huruf dalam tulisan menggambarkan urutan bunyi dalam ucapan, membuat prediksi yang didasarkan pada ilustrasi cerita, menggunakan invented spelling untuk menulis pesannya sendiri, menulis namanya sendiri, dapat menulis huruf atau kata dengan dikte.

Pada saat menstimulasi kemampuan anak untuk: menyebutkan simbol-simbol huruf yang dikenal, mengenal suara huruf awal dari nama benda-benda yang ada di sekitarnya, memahami hubungan antara bunyi dan bentuk huruf, guru membuat materi berupa flash player yang diberi nama program pembelajaran anak cerdas. Program ini dibuat sendiri oleh guru. Program ini 
memuat beberapa konten, yaitu: membaca, menulis, berhitung dan permainan edukatif. Dalam mengenal huruf guru di TK Model Sleman menggunakan konten membaca. Dalam membaca tersebut terbagi lagi menjadi beberapa bagian, yaitu: mengenal huruf, mengenal nama benda dan hewan sekitar dan mengenal suara binatang. Anak-anak dapat mengenal huruf dengan mudah, dikarenakan gambar, suara dan animasi yang menarik.

Selanjutnya, dalam menstimulasi anak untuk memahami arti kata dalam cerita, guru menyiapkan video pembelajaran. Hasil pengamatan menunjukkan bahwa ketika anak-anak menonton video pembelajaran, suasana kelas menjadi kondusif dan terarah. Anak-anak duduk memperhatikan video pembelajaran hingga selesai. Terlihat anak-anak tertarik dengan vieo yang disajikan guru. Mereka mengikuti jalan cerita dengan sesekali membaca teks yang tersedia pada video. Hal ini telah dijelaskan sebelumnya oleh Verhallen (2006, p.17) bahwa "Cerita animasi komputer lebih efektif mendukung untuk pemahaman narasi dan perkembangan bahasa daripada gambar berseri yang tidak bergerak".

\section{Simpulan}

Pelaksanaan penggunaan teknologi multimedia pada pembelajaran literasi diimplementasikan dalam pijakan-pijakan pembelajaran sentra dengan langkah-langkah: (1) pemusatan perhatian dan fokus, (2) orientasi, (3) pemodelan, (4) tahap bermain anak, dan (5) ringkasan. Aspek-aspek kemampuan literasi anak yang distimulasi menggunakan teknologi multimedia adalah: menulis dan membaca namanya sendiri, menyebutkan simbol-simbol huruf yang dikenal, mengenal suara huruf awal dari nama benda-benda yang ada di sekitarnya, memahami hubungan antara bunyi dan bentuk huruf, memahami arti kata dalam cerita.

\section{Daftar Pustaka}

Chee, T. S. \& Wong A.F.L. (2003). Teaching and learning with technology. Singapore: Pearson Prentice Hall.

Essa, L. E. (2002). Introduction to Early Childhood Education 4th. New York: Delmar Learning Family and Community Engagement Research Compendium (2013). Make Every Student Count. How Collaboration among Families, schools, and Communities Ensures student $\begin{array}{llllll}\text { success. } & \text { Diunduh } & \text { pada } & 4 & \text { April } & 2017\end{array}$ http://teacher.scholastic.com/products/face/pdf/research-compendium/Compendium.pdf

Jo, J.T. (2013). Peningkatan Kemampuan Membaca Permulaan Melalui Pemanfaatan Multimedia. Jurnal Pendidikan Usia Dini. 7 (1), 17-48.

Kennedy, E. (2012) Literacy in Early Childhood and Primary Education (3-8 years). Dublin: National Council for Curriculum and Assessment. 
Kompasiana. (2012). Dampak Multimedia Terhadap Minat Baca Masyarakat. Diunduh pada 3 September 2016 dari http://www.kompasiana.com/litamajid/dampak-multimedia-terhadapminat-baca-masyarakat_550f

Malik, S. \& Agarwal. (2012). Use of Multimedia as a New Educational Technology Tool-A Study. International Journal of Information and Education Technology, 2( 5).

Mayer, R. E. (2010). Multimedia Learning Second Edition. USA: Cambridge University Press.

Mullis, I.V.S., Michael O., Pierre, F., et all (2012). PIRLS 2011 International Results in Reading. USA: TIMSS \& PIRLS International Study Center.

Munir. (2012). Multimedia Konsep dan Aplikasi dalam Pendidikan. Bandung: Alfabeta.

Ramli, M., (2013). Aplikasi Teknologi Multimedia dalam Pendidikan. Ittihad Jurnal Kopertais Wilayah XI Kalimantan. 11(19).

Ruhaena, L. (2014). Pengembangan Literasi Anak dengan Pendekatan Multisensori. Jurnal Psikologi. Yogyakarta: UGM.

Snow, C.S. (2008). What counts as Literacy in Early Childhood? Hand book of Early Childhood Development. 274-316. Singapore: C.O.S Printers.

Trehearne, P. (2011). Learning to Write and Loving It!. USA: Library of Congress Cataloguingin-Publication Data.

Trianto (2011). Desain Pengembangan Pembelajaran Tematik Bagi Anak Usia Dini TK/RA \& Anak Usia Kelas Awal SD/MI. Jakarta: Kencana Prenada Media Group

Yin, R. K (2011). Studi Kasus Desain \& Metode. Jakarta: Rajawali Pers 